\title{
Benign Lip Neoplasm
}

National Cancer Institute

\section{Source}

National Cancer Institute. Benign Lip Neoplasm. NCI Thesaurus. Code C3591.

A non-metastasizing neoplasm that arises from the lip. 